Article

\title{
Effect of Palm Oil Clinker (POC) Aggregate on the Mechanical Properties of Stone Mastic Asphalt (SMA) Mixtures
}

\author{
Ali Mohammed Babalghaith ${ }^{1}\left(\mathbb{0}\right.$, Suhana Koting ${ }^{1, *}$, Nor Hafizah Ramli Sulong ${ }^{1,2}$, \\ Mohamed Rehan Karim ${ }^{1}$, Syakirah Afiza Mohammed ${ }^{1}$ and Mohd Rasdan Ibrahim ${ }^{1}$ \\ 1 Center for Transportation Research, Department of Civil Engineering, Faculty of Engineering, University of \\ Malaya, Kuala Lumpur 50603, Malaysia; bablgeath@hotmail.com (A.M.B.); \\ hafizah.ramlisulong@qut.edu.au (N.H.R.S.); mrehan57@gmail.com (M.R.K.); \\ syakirahafiza@unimap.edu.my (S.A.M.); rasdan@um.edu.my (M.R.I.) \\ 2 School of Civil and Environmental Engineering, Science and Engineering Faculty, Queensland University of \\ Technology, 2 George Street, Brisbane, QLD 4000, Australia \\ * Correspondence: suhana_koting@um.edu.my
}

Received: 29 February 2020; Accepted: 26 March 2020; Published: 30 March 2020

\begin{abstract}
Aggregate composition has a pivotal role in ensuring the quality of pavement materials. The use of waste materials to replace the aggregate composition of asphalt pavement leads to green, sustainable, and environmentally friendly construction, which ultimately preserves nature by reducing the need to harvest materials from natural sources. Using the Marshall mix design, the main objective of this paper is to investigate the effects of waste palm oil clinker (POC) as fine aggregates replacement on the properties of stone mastic asphalt (SMA) mixture. Six groups of asphalt mixtures were prepared using different percentages of palm oil clinker content $(0 \%, 20 \%$, $40 \%, 60 \%, 80 \%$, and $100 \%$ ). To determine the Marshall properties and select the optimum binder content, asphalt mixture samples with different percentages of asphalt binder content $(5.0 \%, 5.5 \%$, $6.0 \%, 6.5 \%$, and $7.0 \%$ ) were prepared for each group. The results showed that the palm oil clinker was appropriate for use as a fine aggregate replacement up to $100 \%$ in SMA mixture and could satisfy the mix design requirements in terms of Marshall stability, flow, quotient, and volumetric properties. However, the percentage of palm oil clinker replacement as fine aggregate has merely influenced the optimum binder content. Furthermore, there were improvements in the drain down, resilient modulus and indirect tensile fatigue performances of the SMA mixture. In conclusion, the use of POC as fine aggregates replacement in SMA mixture indicates a good potential to be commercialized in flexible pavement construction.
\end{abstract}

Keywords: palm oil clinker; hot mix asphalt; Marshall properties; stone mastic asphalt; waste materials; sustainable pavement

\section{Introduction}

In recent times, natural resources are being quickly depleted due to the enormous amount of raw materials being consumed worldwide. With the growth in the population, there are concomitant increases in waste generated by the increasing demand of new agricultural, manufacturing and construction industries, which results in a large amount of waste materials being deposited in landfills every year. Hence, researchers are trying to find new solutions to reduce the negative impact of these wastes on the environment. For example, waste materials are used to replace the original constructions materials such as binders, aggregates, and fibers. This leads to green, sustainable, and environmentally friendly construction. The use of waste materials in asphalt pavement minimizes the construction costs 
and preserves nature by reducing the need to harvest aggregates from natural sources [1]. Using waste materials in the asphalt pavement not only reduces the environmental problems but also improves some of the properties of the asphalt pavement [2]. With respect to asphalt pavement, many researchers have studied the use of waste materials as aggregate in asphalt mixtures, such as crushed glass [3], steel slag [4], plastics [5], recycled pavement [6], recycled concrete demolition [7-9], coal bottom ash [10], and mining waste [11].

Palm oil trees, as shown in Figure 1, are planted in many countries for food applications such as cooking oil and margarines, and for non-food applications such as animal feed, biodiesel and energy generation. Malaysia, Indonesia, and Thailand produced almost $91 \%$ of the total world's palm oil in 2015. Hence, Malaysia, being one of the largest producers and manufacturers of palm oil products contributes $32 \%$ of the world supply of palm oil [12]. Malaysia alone has produced 19.86 million tons of palm oil and exported 18.47 million tons of palm oil in 2019 [13]. Palm oil processing activities produce only $10 \%$ oils from fresh fruit and kernel while the remaining $90 \%$ remain in the form of waste is still not used for the industry [14]. The processing of palm oil generates various types and forms of waste materials and by-products, such as empty fruit bunches, palm oil mill effluent, sterilizer condensate, fibers and kernel shells [15]. Malaysia produced about 50 million tonnes of palm oil biomass every year and it is expected to be 100 million tonnes in 2020 [16]. The oil palm biomass, such as palm oil shell and fibers, was used as boiler fuel for power generation purposes $[17,18]$. This process creates large amounts of a new waste material called a palm oil clinker-an aggregate like a porous stone, grey in color, irregular, and flaky [19].

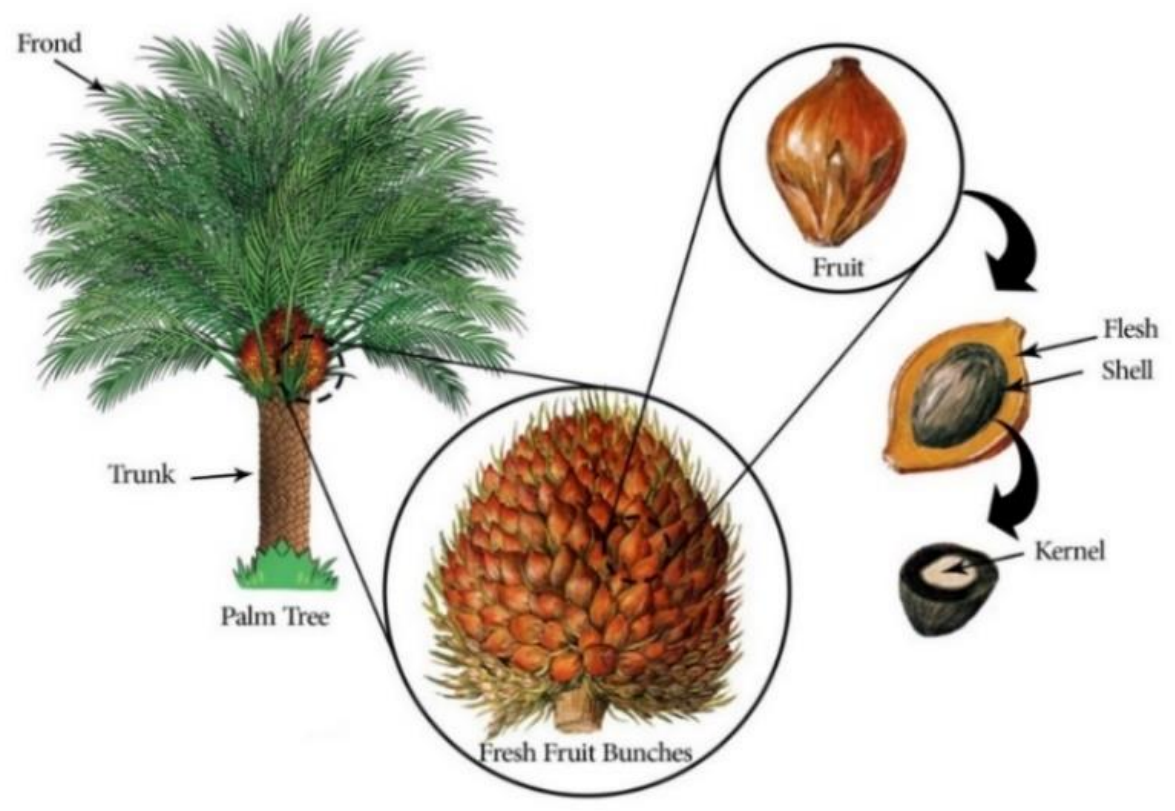

Figure 1. Palm oil tree.

Many studies have been conducted on the use of palm oil clinker (POC) as a replacement to concrete construction materials, such as aggregate [20-23], and cement [24-27]. In highway pavement, a number of researchers have studied the use of palm oil waste as a filler [28-32]. Ahmad et al. [31] investigated the practical use of Palm oil fuel ash (POFA) at different percentages as a filler in asphalt pavement. They found that the addition of $3 \%$ POFA by weight of total aggregate could increase the stability and resilient modulus of asphalt pavement. Moreover, Kamaluddin [29] studied the use of palm oil fuel ash in stone mastic asphalt (SMA) mixture as a filler material, and the results indicated that the optimum value of POFA by weight of filler content is $50 \%$.

To date, there are very limited studies that have investigated the use of palm oil clinker as aggregate replacement in highway pavement. This research presents an experimental research on the use of 
palm oil clinker waste with different percentages in SMA as fine aggregate replacement. The main objective was to study the effect of aggregate replacement on the properties of SMA, and to compare with the control mixture containing normal granite aggregate. The Marshall stability, Marshall flow, and volumetric tests were conducted on five different asphalt mixtures containing different contents of palm oil clinker $(20 \%, 40 \%, 60 \%, 80 \%$, and $100 \%)$ and one asphalt mixture containing original aggregate (control mix). Finally, based on optimum binder content results, different sets of samples were prepared and tested for drain down test, resilient modulus test, and indirect tensile fatigue test.

\section{Materials}

\subsection{Asphalt Binder}

In this study, $80 / 100$ penetration grade bitumen was used as the binder. To maintain the quality of the binder during binder testing preparations, the 80/100 binder was transferred from the drum to one-liter containers. The properties of the asphalt binder are presented in Table 1.

Table 1. Properties of 80/100 asphalt binder.

\begin{tabular}{cccc}
\hline Property & Reference & Value & Requirement \\
\hline Penetration @ $25^{\circ} \mathrm{C}(0.1 \mathrm{~mm})$ & ASTM D0005-13 & 87 & $80-100$ \\
Softening Point $\left({ }^{\circ} \mathrm{C}\right)$ & ASTM D0036-95 & 46 & $45-52$ \\
Rotational Viscosity @ $135^{\circ} \mathrm{C}$, (cps) & ASTM D4402-02 & 312 & $<3000$ \\
Rotational Viscosity @ $165^{\circ} \mathrm{C}$, (cps) & ASTM D4402-02 & 100 & $<3000$ \\
Specific Gravity @ $25^{\circ} \mathrm{C}$ & ASTM D0070-09 & 1.020 & - \\
$\mathrm{G}^{*} / \mathrm{sin} \delta @ 58^{\circ} \mathrm{C}(\mathrm{kpa})$ & ASTM D7175-15 & 1.576 & $>1.0$ \\
\hline
\end{tabular}

\subsection{Aggregates}

The crushed granite aggregates used in this study were collected from the same aggregate supplier to maintain the quality and results reliability. The dried materials were sieved, and the materials retained on each sieve were transferred to a container and labeled with the aggregate size. The aggregate gradation used in this study was stone mastic asphalt (SMA) 20. The gradation of SMA20 was according to the specification of the Malaysian Public Works-Road Department (Jabatan Kerja Raya-JKR) [33]; as shown in Table 2 and Figure 2.

Table 2. Stone mastic asphalt (SMA)20 aggregate gradation.

\begin{tabular}{cccccc}
\hline $\begin{array}{c}\text { Sieve Size } \\
(\mathbf{m m})\end{array}$ & \multicolumn{3}{c}{ \% Passing } & \% Retained & Weight $(\mathbf{g})$ \\
\cline { 2 - 4 } & Min. & Max. & Mid. & & \\
\hline 19 & 100 & 100 & 100.0 & 0.0 & 0.0 \\
12.5 & 85 & 95 & 90.0 & 10.0 & 110 \\
9.5 & 65 & 75 & 70.0 & 20.0 & 220 \\
4.75 & 20 & 28 & 24.0 & 46.0 & 506 \\
2.36 & 16 & 24 & 20.0 & 4.0 & 44 \\
0.600 & 12 & 16 & 14.0 & 6.0 & 66 \\
0.300 & 12 & 15 & 13.5 & 2.0 & 5.5 \\
0.075 & 8 & 10 & 9.0 & 3.0 & 49.5 \\
Pan & & & & 9.0 & 99 \\
\hline
\end{tabular}




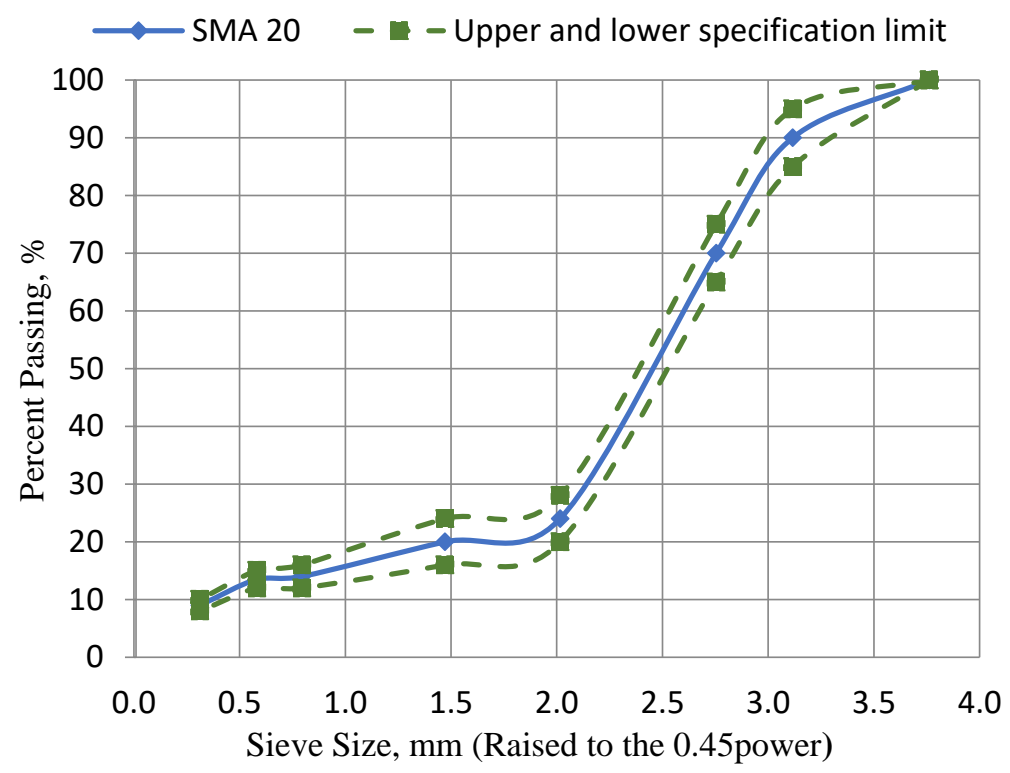

Figure 2. SMA20 aggregate gradation.

Meanwhile, the physical properties tests for SMA20 aggregate were also carried out. The physical properties values for the aggregate are tabulated in Table 3.

Table 3. Physical properties of SMA20 aggregate.

\begin{tabular}{cccc}
\hline Property & Test Method & Value (\%) & Requirement \\
\hline Los Angeles abrasion & ASTM: C131-14 & 19.8 & $<30 \%$ \\
Flakiness index & BS 182: Part3 & 7.3 & $<20 \%$ \\
Elongation index & BS 182: Part3 & 13.4 & $<20 \%$ \\
Impact value & BS 812: Part3 & 10.3 & $<15 \%$ \\
\hline
\end{tabular}

\subsection{Palm Oil Clinker and Fuel Ash}

The palm oil fuel ash and clinker were obtained from a local factory that processes palm oil. The palm oil clinker was collected as large chunk clinker, as shown in Figure 3a. The large chunk clinker was then crushed to become a fine aggregate, as shown in Figure $3 \mathrm{~b}$. The crushed materials were sieved and each sieve size was transferred to a separate container. Palm oil fuel ash was collected in powder form and sieved through a $0.075 \mathrm{~mm}(\# 200)$ sieve.

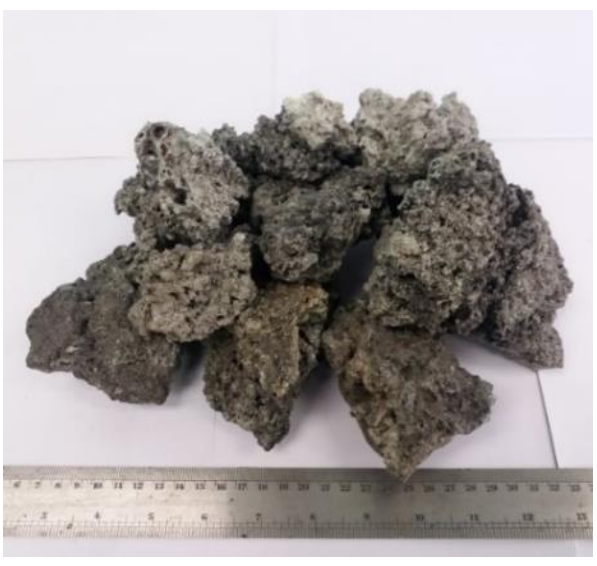

(a)

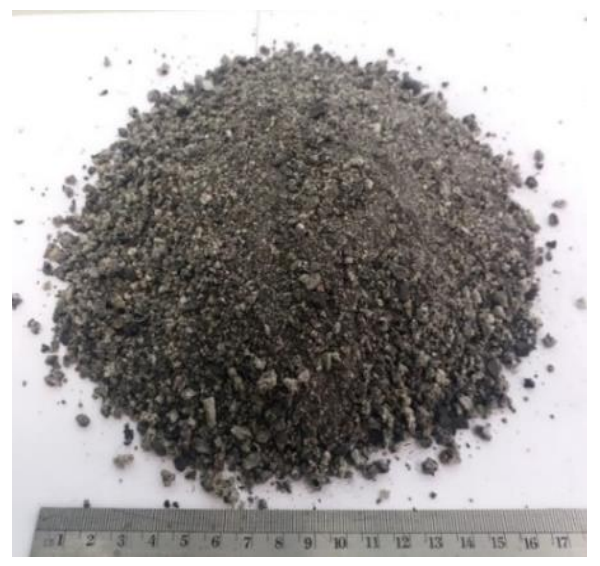

(b)

Figure 3. Palm oil clinker; (a) large chunk clinker, (b) crushed clinker. 


\section{Experimental Design}

The mix design was used to obtain the optimum binder content for the mixtures to achieve high resistance to deformation and cracking. The method consisted of three basic steps: Aggregate selection, asphalt binder selection, and optimum binder content determination. In this study, the Marshall mix design method was used, as it is considered to be one of the most common methods, well proven, and requires relatively light, portable, and inexpensive equipment. The general steps of the experimental work are illustrated in Figure 4.

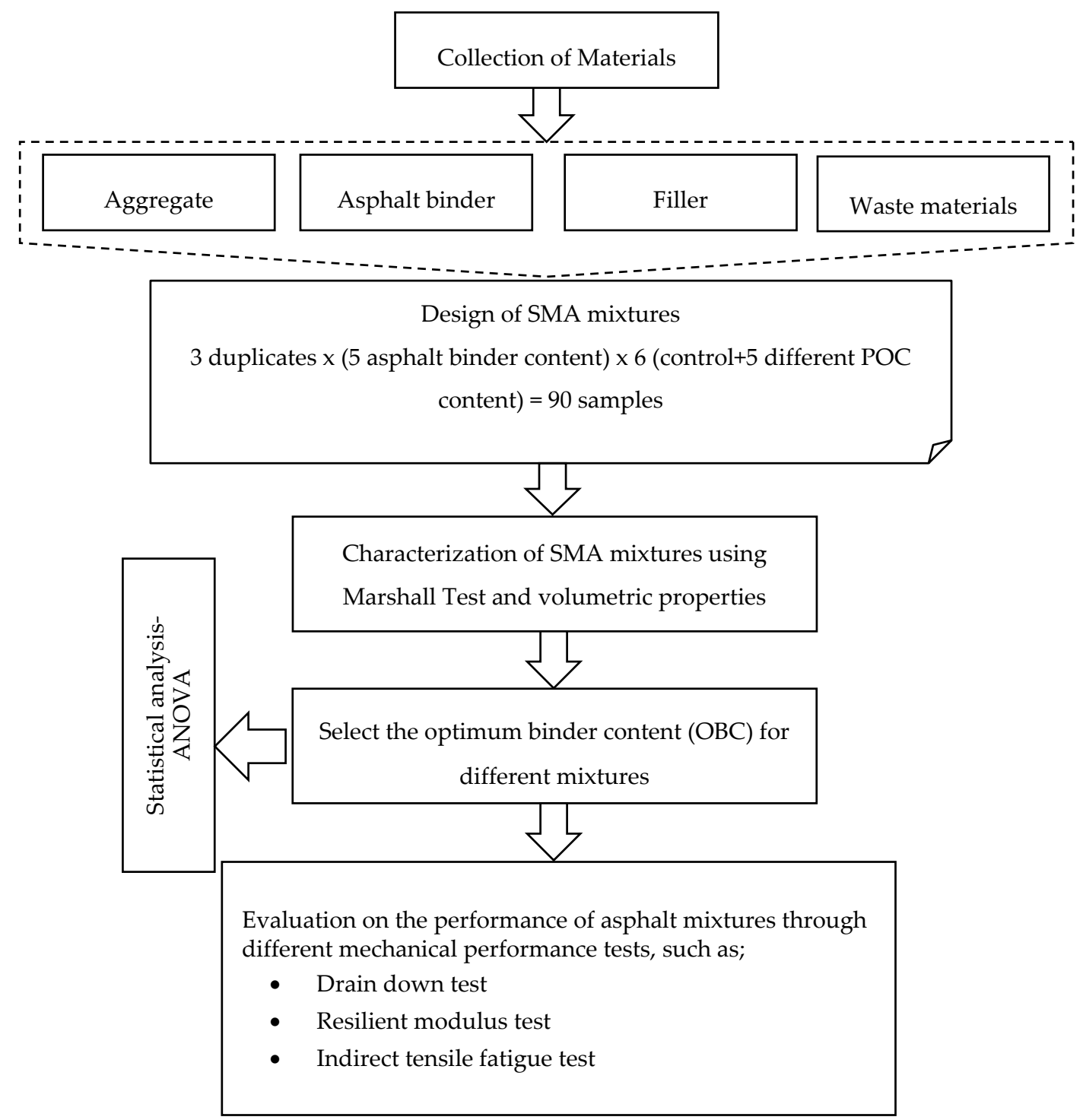

Figure 4. Experimental work.

In this study, six groups of asphalt mixtures were prepared using different contents of palm oil clinker $(0 \%, 20 \%, 40 \%, 60 \%, 80 \%$, and $100 \%$ ) for the granite fine aggregate (passing sieve size $4.75 \mathrm{~mm}$ ) replacement. The group with $0.0 \%$ waste materials was used as the control mixture. For each group, three duplicate samples with a constant content of palm oil clinker and different asphalt binder content $(5.0 \%, 5.5 \%, 6.0 \%, 6.5 \%$, and $7.0 \%)$ were prepared to determine the Marshall properties and select the optimum binder content. Then, the statistical analysis, namely, the analysis of variance (ANOVA) test was carried out using SPSS software. Finally, to evaluate the mechanical performance of optimum 
SMA mixtures, different sets for each group were prepared. The SMA mixtures samples were tested for drain down, resilient modulus, and indirect tensile fatigue performance.

\subsection{Preparation of Samples}

Samples of approximately 1100 grams were weighed according to the combination of aggregates, then heated to a temperature of $160-170{ }^{\circ} \mathrm{C}$ for 3 hours. At the same time, the asphalt binder was heated in another oven at a mixing temperature of $150-155^{\circ} \mathrm{C}$ for 1 hour. Using the dry process method, all ingredients were mixed together, then the required asphalt binder content $(5.0 \%, 5.5 \%, 6.0 \%, 6.5 \%$, and $7.0 \%$ by weight of mix) was added and mixed thoroughly to form homogenous mixtures. The blended mixture was put into a Marshall mold and moved to the Marshall compactor. Then, each sample was subjected to 50 blows on each side at a compaction temperature of $140{ }^{\circ} \mathrm{C}-145^{\circ} \mathrm{C}$ according to the specifications of the Malaysian Public Works Department for road works [33]. Finally, they were left to cool for 24 hours at a normal temperature then removed from the mold using a jack and kept in the laboratory until further testing.

\subsection{Marshall Test}

\subsubsection{Stability, Flow and Quotient}

The Marshall stability of asphalt mixture is defined as maximum load value during the test before the compacted sample failure at a temperature of $60^{\circ} \mathrm{C}$, and a loading rate of $5.08 \mathrm{~cm}$ per minute [34]. It was determined according to ASTM D6927 [35]. The plastic flow at the failure point of the mix is called the Marshall flow value, which is expressed in units of $0.25 \mathrm{~mm}$ and is measured by the sample vertical deformation in the direction of the applied load. The Marshall flow indicates the plasticity and flexibility properties of mixtures. According to the JKR specifications for SMA, the acceptable range is from 2 to $4 \mathrm{~mm}$ [33]. The minimum value controls the brittleness and strength, while the maximum value dictates the plasticity and maximum asphalt binder content of the mixture [36]. The Marshall stability value divided by the Marshall flow value is called the Marshall quotient, which can be used as an indicator of resistance to rutting or permanent deformation of the asphalt mixture [11].

\subsubsection{Volumetric Properties}

The volume of asphalt binder and aggregates is affected by the volumetric properties of the required asphalt mixture. The volumetric properties of the asphalt mixture are among the important factors that affect the pavement performance and durability [37]. In this study, the volumetric properties, such as density, air voids, and voids filled with asphalt binder, were calculated. The density was determined according to ASTM D2726 [38], and the air voids and voids filled with asphalt binder were determined according to ASTM D3203 [39].

\subsubsection{Optimum Asphalt Content Selection}

To optimize the asphalt mixtures, the Marshall procedure (ASTM D6926 [40]) was applied. Five percentages of asphalt binder $(5.0 \%, 5.5 \%, 6.0 \%, 6.5 \%$, and $7.0 \%$ by weight of mix) were used, and, for each percentage, three duplicate samples were prepared using the Marshall compactor. In general, the selection of the optimum binder content (OBC) depends on the stability, flow, specific gravity, and voids in the mixture. However, in the SMA mixtures, the air voids were considered to be the main factor to select the optimum binder content [41-44]. Moreover, the asphalt binder percentage that produces approximately $4 \%$ air voids will provide less asphalt binder bleeding and better rutting resistance [43]. In this study, the optimum asphalt contents for all SMA mixtures were selected to produce $4 \%$ air voids and also checked for the mix design criteria specified by JKR [33]. Statistical analysis was done using SPSS software at the level of $5 \%$ significance. 


\subsection{Mixture Performance Tests}

To evaluate the performance and mechanical properties of POC as fine aggregates replacement in SMA20 mixture, drain down, resilient modulus, and indirect tensile fatigue tests were performed. Each test is described in the following sections.

\subsubsection{Drain Down Test}

Drain down situation is the portion of the mixture, namely, fines and asphalt binder, which separates and flows downward through the mixture, and is more significant for SMA mixtures than conventional (dense-graded) mixtures. This test was carried out in accordance with ASTM D6390 [45]. This test is to simulate the conditions that the mixture is likely to encounter as it is produced, stored, transported, and placed. The test is carried out on loose mixtures at the optimum binder content. This is to ensure that the engineering properties of the binder drain down of the SMA mixture is within the require or acceptable level. The main procedure of the test is to place loose SMA mixture in a wire basket, which has been fabricated using standard $6 \mathrm{~mm}$ sieve cloth. The basket and the loose SMA mixture are then placed in an oven for one hour at $170{ }^{\circ} \mathrm{C}$. The mass of portion from fines and asphalt binder draining from the mixture was measured. This mass was recorded as a percentage of the initial sample weight. The maximum drain down of SMA mixture is $0.3 \%$ by weight of the mixture [33].

\subsubsection{Resilient Modulus Test}

The resilient modulus test is the most appropriate and common test to measure the stiffness modulus of asphalt mixtures. It was carried out using a universal materials testing apparatus (UMATTA) machine, in accordance with ASTM D4123 [46]. An average of $101.7 \mathrm{~mm}$ diameter and $65 \pm 1 \mathrm{~mm}$ thickness sample was prepared for resilient modulus test. The test was carried out at four temperatures, namely $5{ }^{\circ} \mathrm{C}, 25^{\circ} \mathrm{C}, 35^{\circ} \mathrm{C}$, and $40^{\circ} \mathrm{C}$. The samples were left in the chamber at the desired temperature for a minimum of 3 hours before the test. The stiffness modulus of the samples was calculated automatically after the test, which is based on the following equation:

$$
\text { Resilient Modulus }(\mathrm{MPa})=\frac{P(v+0.25)}{H x T}
$$

where, $\mathrm{P}$ is the peak load $(\mathrm{N})$; $\mathrm{v}$ is the Poisson's ratio; $\mathrm{T}$ is the average thickness of the sample $(\mathrm{mm})$ and $\mathrm{H}$ is total recoverable deformation on the horizontal axis $(\mathrm{mm})$. In this test, all samples were tested at three different points of vertical loading. Finally, the average result from the three samples was calculated and recorded.

\subsubsection{Indirect Tensile Fatigue Test}

Asphalt mixture fatigue performance is linked to the service life of the roadway. The better the fatigue performance of the asphalt mixture, the longer the service life of the pavement. The fatigue life of asphalt mixture depends on the mixture properties such as grade and amount of asphalt binder, aggregates gradation, and mixture air voids [47]. The fatigue performance of the asphalt mixture can be characterized by four-point bending fatigue test or indirect tensile fatigue test [48]. Indirect tensile fatigue test is an effective method that has been used in many studies to investigate the fatigue performance $[3,47,49,50]$. This test can be carried out in two modes, either in controlled stress or controlled strain.

In the controlled stress mode, the applied stress is kept constant, and the strain values are changeable; while in controlled strain mode, the strain value is kept constant and the stress values are changeable. In this study, indirect tensile fatigue test was performed by a UMATTA machine in controlled stress mode according to EN 12697-24 [51]. The loading shape used was a haversine signal loading force, i.e., $2600 \mathrm{~N}$. The loading time was $0.1 \mathrm{~s}$, follows by a rest period of $0.4 \mathrm{~s}$. The test was carried out at $25^{\circ} \mathrm{C}$. The vertical deformation of the sample was recorded during the test. The 
fatigue life was defined as the number of load cycles reached when the sample cracked, or when the permanent vertical deformation reached the maximum value of $9 \mathrm{~mm}$ [47].

\section{Results and Discussion}

\subsection{Marshall Stability}

The average Marshall stability for the three duplicate samples from each asphalt mixture are shown in Table 4 and presented in Figure 5. The results indicate that the values of stability for all asphalt binder contents vary in tandem with the palm oil clinker content. The stability values increased with higher percentage of POC replacement (with slight reduction at $80 \%$ replacement). This improvement might be due to the fiber content in the palm oil clinker, where the fiber increased the strength and ductility of the mixtures. Moreover, the addition of asphalt binder into the mixture resulted in a decrease in the stability value because of reduced contact point between the aggregates within the asphalt mixture [34].

Table 4. Marshall stability with different ratios of binder content and palm oil clinker (POC).

\begin{tabular}{ccccccc}
\hline & \multicolumn{5}{c}{ Marshall Stability (kN) } \\
\cline { 2 - 7 } Binder Content (\%) & \multicolumn{5}{c}{ POC Content (\%) } \\
\cline { 2 - 7 } & $\mathbf{0}$ & $\mathbf{2 0}$ & $\mathbf{4 0}$ & $\mathbf{6 0}$ & $\mathbf{8 0}$ & $\mathbf{1 0 0}$ \\
\hline 5.0 & 8.69 & 9.34 & 9.70 & 9.94 & 9.26 & 11.21 \\
5.5 & 8.27 & 9.52 & 8.81 & 10.22 & 8.61 & 10.75 \\
6.0 & 8.34 & 8.16 & 7.62 & 8.10 & 9.11 & 9.31 \\
6.5 & 8.61 & 8.33 & 7.76 & 8.91 & 8.67 & 10.13 \\
7.0 & 8.33 & 8.11 & 7.06 & 8.30 & 8.24 & 9.22 \\
\hline
\end{tabular}

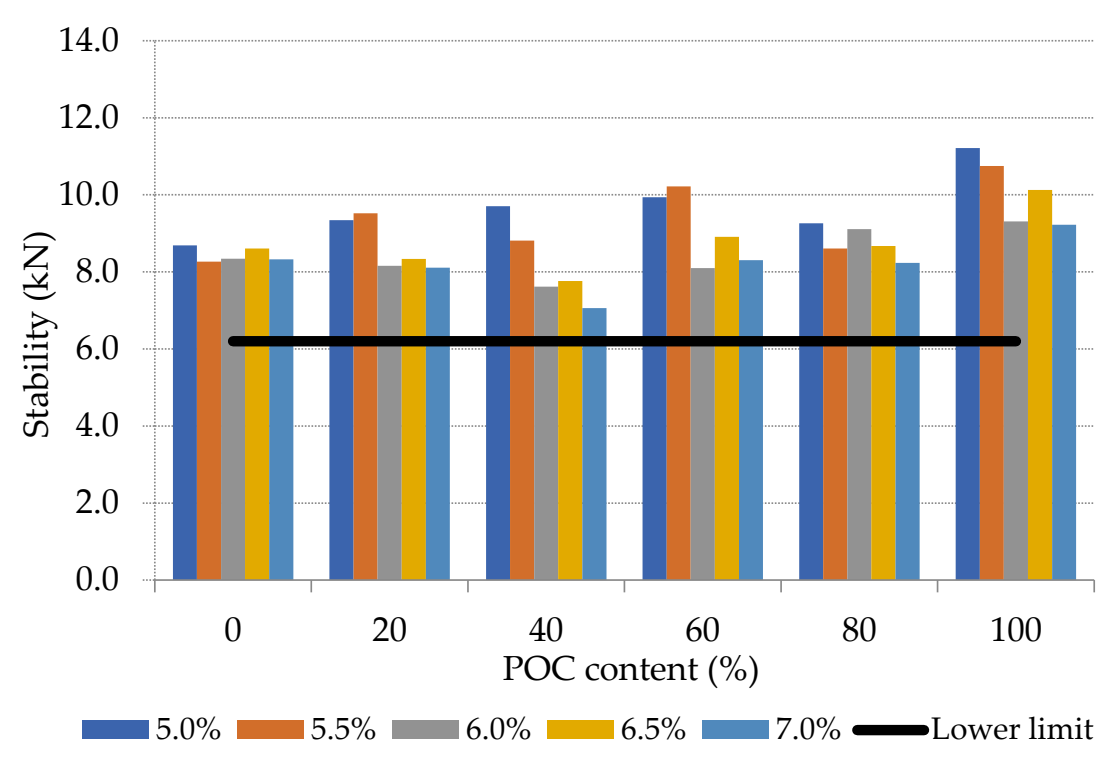

Figure 5. Marshall stability for different clinker and binder contents.

Table 4 shows that the control mixture and all aggregate replacement mixtures satisfied the recommended minimum stability value of $6.2 \mathrm{kN}$ according to the JKR specifications for SMA20 [33]. Therefore, palm oil clinker has proven to be an alternative waste material for fine aggregate replacement in SMA20. 


\subsection{Marshall Flow and Quotient}

The Marshall flow values versus palm oil clinker contents for each asphalt binder content are summarized in Table 5 and illustrated in Figure 6. There was no clear trend on the influence of POC contents on the flow values. However, all of the asphalt mixtures Marshall flow values were within the acceptable range of values (2-4 mm) recommended by JKR for SMA20 [33].

Table 5. Marshall flow with different ratios of binder content and POC.

\begin{tabular}{ccccccc}
\hline & \multicolumn{6}{c}{ Marshall Flow (mm) } \\
\cline { 2 - 7 } Binder Content (\%) & \multicolumn{6}{c}{ POC Content (\%) } \\
\cline { 2 - 7 } & $\mathbf{0}$ & $\mathbf{2 0}$ & $\mathbf{4 0}$ & $\mathbf{6 0}$ & $\mathbf{8 0}$ & $\mathbf{1 0 0}$ \\
\hline 5.0 & 3.22 & 3.04 & 4.18 & 2.81 & 3.05 & 2.61 \\
5.5 & 3.65 & 3.33 & 3.82 & 3.55 & 3.29 & 3.53 \\
6.0 & 3.70 & 3.59 & 3.00 & 4.22 & 2.84 & 3.73 \\
6.5 & 3.67 & 3.69 & 3.19 & 3.10 & 3.74 & 4.20 \\
7.0 & 2.61 & 3.40 & 2.98 & 3.48 & 3.12 & 3.96 \\
\hline
\end{tabular}

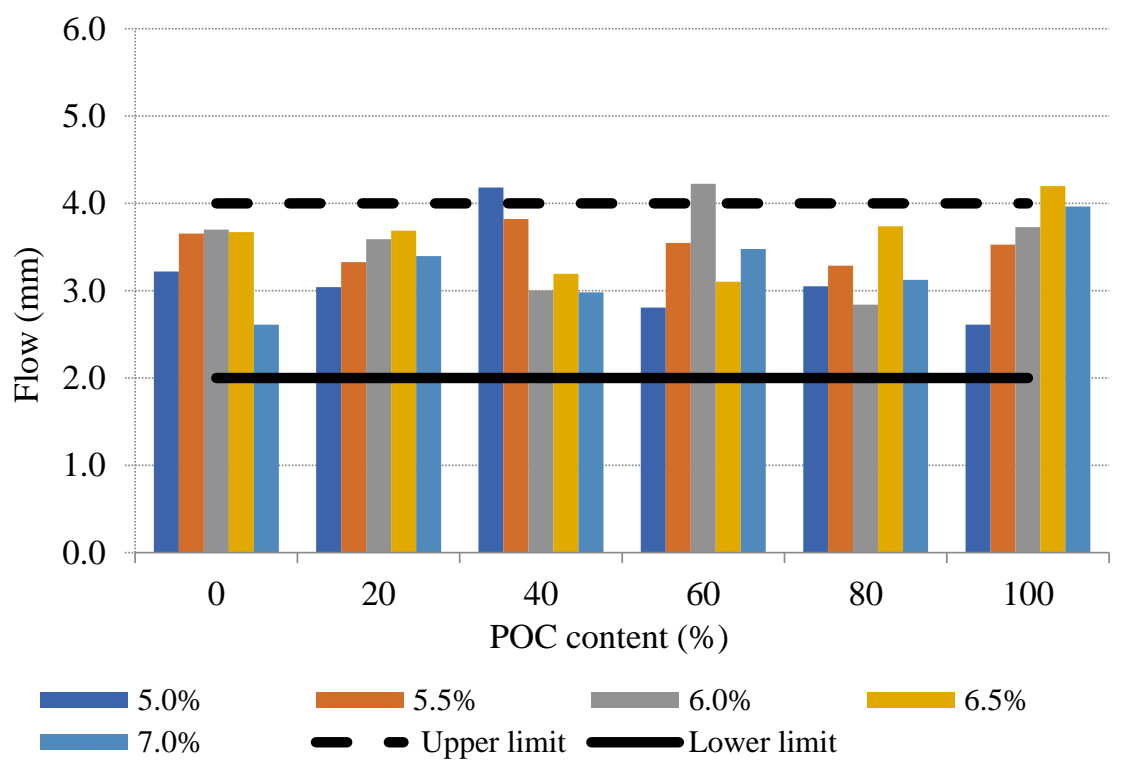

Figure 6. Marshall flow for the different POC and binder contents.

Figure 7 shows the Marshall quotient values versus palm oil clinker for different asphalt binder contents. Most of the asphalt mixtures quotient values were within the acceptable range of $2-4 \mathrm{kN} / \mathrm{mm}$, except for the mix with $60 \%$ clinker and $6.0 \%$ asphalt binder for which the value was slightly lower than the prescribed lower limit. Therefore, it can be concluded that the asphalt mixtures with POC as aggregate replacement have the required strength and stiffness to resist the permanent deformation under traffic loads. 


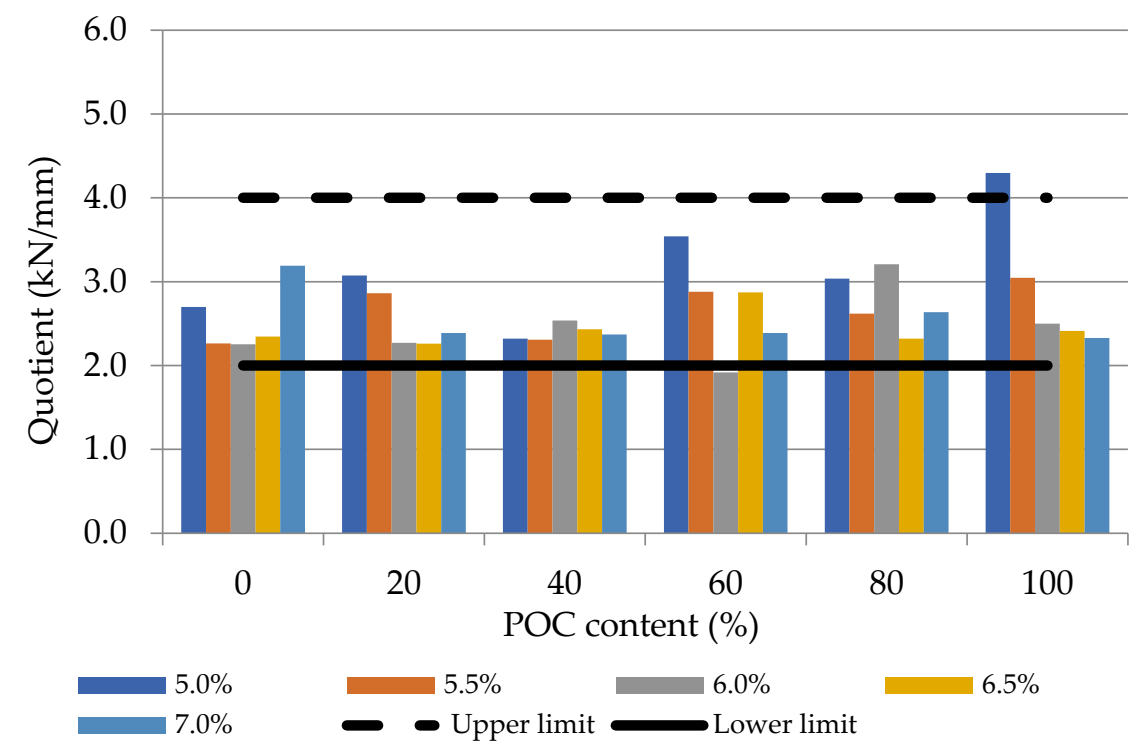

Figure 7. Marshall quotient for different POC and binder contents.

\subsection{Mixture Density}

The density values of all the mixtures versus the palm oil clinker for different asphalt binder contents are graphically presented in Figure 8.

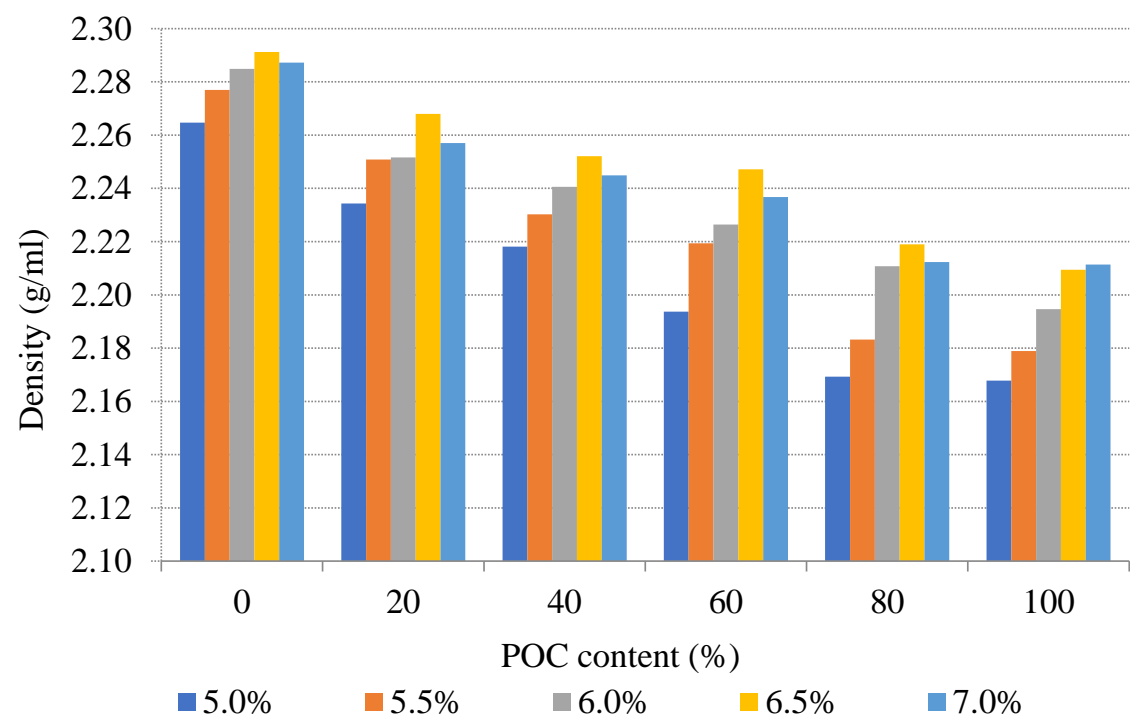

Figure 8. Mixture density for different POC and binder contents.

The results show that the palm oil clinker aggregate affected the density of the mixture and had a similar trend, and that, for any asphalt binder content, the density value of the compacted sample decreased with an increase in the clinker aggregate replacement. Moreover, all the mixtures replaced with the clinker aggregate had lower density values compared to the control mix, which is because of the lower specific gravity of palm oil clinker compared to the normal aggregates.

Moreover, for each particular POC content, the trend of density variation with different alsphalt binder contents followed almost a similar feature. The density kept increasing until $6.5 \%$ asphalt binder content, then reduced afterwards. The main reason for the increment in density is due to the asphalt binder filling the air voids between the aggregates. 


\subsection{Air Voids and the Void Filled with Binder}

A void in the mix is one of the important parameters for asphalt mix designs as it is used to determine the optimum asphalt binder for the SMA mixes [41-43]. The performance of the asphalt mixture is dependent on the air voids in the mix. Too many air voids in the mixture lead to asphalt cracking due to the low asphalt binder content, which fails to coat the aggregates in the mixture, while too few air voids in the mixture may result in more deformation and asphalt binder bleeding [52].

The mixtures air void values versus palm oil clinker for different asphalt binder contents are tabulated in Table 6 and graphically presented in Figure 9.

Table 6. Air voids in mixtures with different ratios of binder content and POC.

\begin{tabular}{ccccccc}
\hline & \multicolumn{6}{c}{ Mixture Air Void (\%) } \\
\cline { 2 - 7 } Binder Content (\%) & \multicolumn{5}{c}{ POC Content (\%) } \\
\cline { 2 - 7 } & $\mathbf{0}$ & $\mathbf{2 0}$ & $\mathbf{4 0}$ & $\mathbf{6 0}$ & $\mathbf{8 0}$ & $\mathbf{1 0 0}$ \\
\hline 5.0 & 6.62 & 6.46 & 6.49 & 7.01 & 7.46 & 7.00 \\
5.5 & 5.44 & 5.10 & 5.32 & 5.27 & 6.23 & 5.89 \\
6.0 & 4.43 & 4.40 & 4.35 & 4.32 & 4.40 & 4.57 \\
6.5 & 3.48 & 3.04 & 3.07 & 2.76 & 3.40 & 3.29 \\
7.0 & 2.96 & 2.84 & 2.72 & 2.56 & 3.04 & 2.56 \\
\hline
\end{tabular}

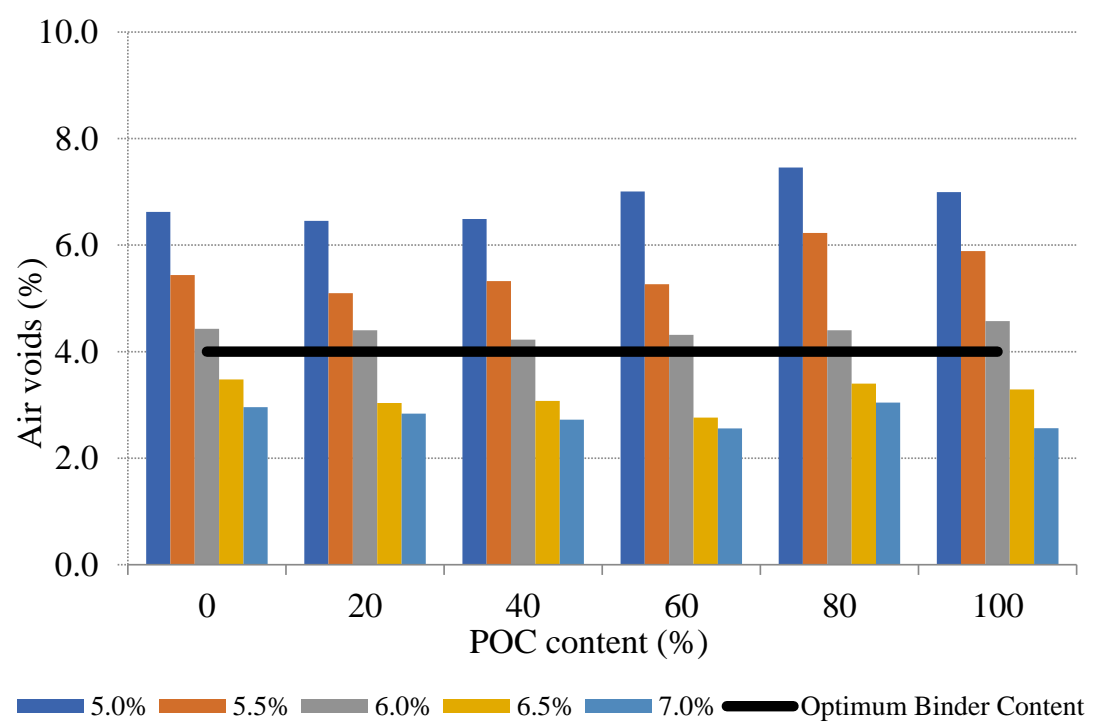

Figure 9. Air voids for different POC and binder contents.

From Figure 9, it can be seen that with an increase in the palm oil clinker aggregate replacement, the air void values of the mixtures had a similar trend and were approximately stable, which means that replacing the original aggregate with palm oil clinker aggregate has no effect on the mixtures air void values. However, there was a significant effect on the mixtures' air voids for different asphalt binder content, where the values decreased as the asphalt binder contents increased. The same behavior was observed by several previous studies $[5,9,36,41,42,52]$. The reason behind this decrement is due to the asphalt binder filling the air voids. For all POC replacement mixtures, $6.5 \%$ and $7.0 \%$ binders were not acceptable as the air voids' percentages were less than the desired value of $4.0 \%$, which may have resulted in more deformation and asphalt binder bleeding. On the other hand, too many air voids, as shown in $5.0 \%$ and $5.5 \%$ binders, is also not preferable as low asphalt binder content may cause cracking in asphalt pavement.

The results for voids filled with asphalt (VFA) versus palm oil clinker for different asphalt binder contents are tabulated in Table 7 and presented in Figure 10. It shows that, for all asphalt binder 
contents, an increase in palm oil clinker content caused the VFA to approximately level off, which means that a change in the clinker content did not affect the VFA values. However, there was a significant effect on the VFA values versus the asphalt binder content. This shows that the VFA values increased when the asphalt binder contents increased. This behavior was confirmed in other researches $[5,36,41]$.

Table 7. Mixtures voids filled with asphalt (VFA) with different ratios of binder content and POC.

\begin{tabular}{ccccccc}
\hline & \multicolumn{6}{c}{ Mixture VFA (\%) } \\
\cline { 2 - 7 } Binder Content (\%) & \multicolumn{5}{c}{ POC Content (\%) } \\
\cline { 2 - 7 } & $\mathbf{0}$ & $\mathbf{2 0}$ & $\mathbf{4 0}$ & $\mathbf{6 0}$ & $\mathbf{8 0}$ & $\mathbf{1 0 0}$ \\
\hline 5.0 & 62.64 & 62.93 & 62.64 & 60.55 & 58.79 & 60.32 \\
5.5 & 69.31 & 70.49 & 69.32 & 69.45 & 65.42 & 66.65 \\
6.0 & 75.22 & 75.07 & 75.84 & 75.22 & 74.74 & 73.95 \\
6.5 & 80.77 & 82.64 & 82.36 & 83.83 & 80.63 & 81.07 \\
7.0 & 84.18 & 84.53 & 84.98 & 85.73 & 83.32 & 85.63 \\
\hline
\end{tabular}

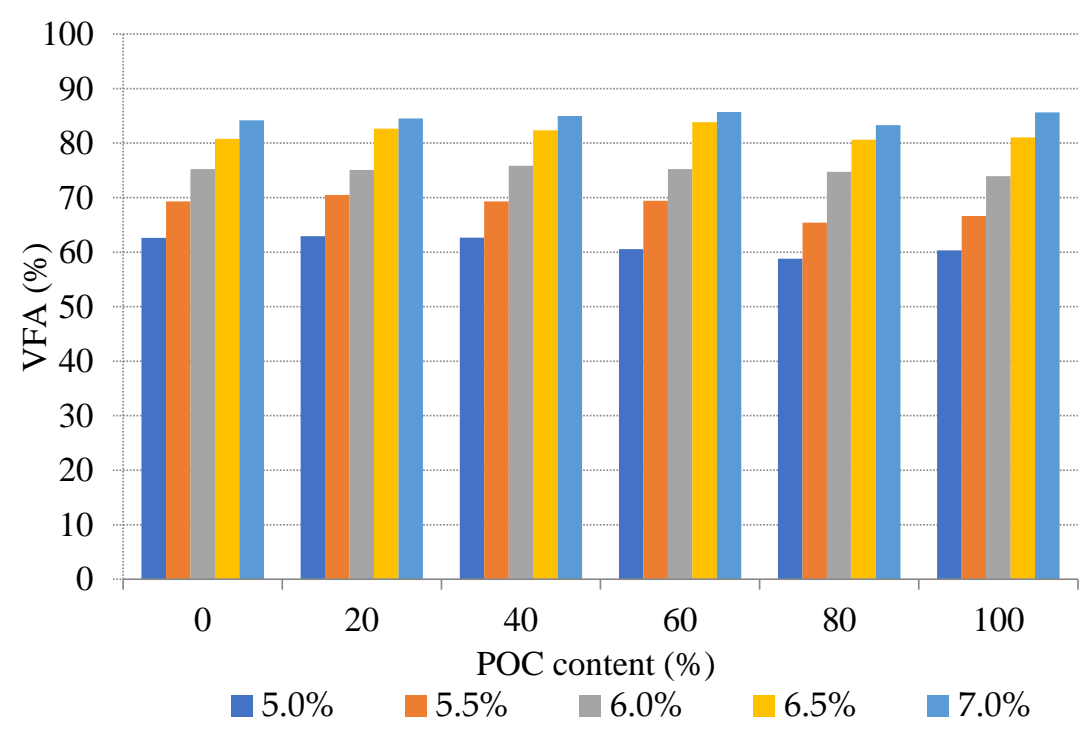

Figure 10. VFA for different POC and binder contents.

\subsection{Asphalt Content Optimization}

For each asphalt mixture group, five percentages of asphalt binder $(5.0 \%, 5.5 \%, 6.0 \%, 6.5 \%$, and $7.0 \%$ by weight of mix) were used to determine the optimum asphalt content. The optimum asphalt contents for all SMA mixtures that produce $4 \%$ air voids were selected and are shown in Figure 11.

Statistical analysis was done using analysis of variance (ANOVA) to evaluate the effect of POC on the optimum asphalt content, and the hypothesis test was utilized to test whether the differences in the optimum asphalt content between all the mixtures were statistically significant. In this hypothesis test, the null hypothesis $\mathrm{H} 0$ is $\mu 1=\mu 2=\mu 3=\mu 4=\mu 5=\mu 6$ and the alternative hypothesis $\mathrm{H} 1$ is $\mu 1 \neq \mu 2 \neq \mu 3 \neq \mu 4 \neq \mu 5 \neq \mu 6$, where $\mu 1, \mu 2, \mu 3, \mu 4, \mu 5$, and $\mu 6$ represent the mean value of the optimum asphalt content for the different mixtures. The descriptive statistics results are shown in Table 8 , and the ANOVA results are shown in Table 9. It can be seen that the differences in the optimum asphalt content were not statistically significant since the p-value (0.578) obtained from the statistical analysis was higher than the alpha value, 0.05 , used in the statistical analysis. Also, the F-ratio (0.787) value was less than 1 , which immediately indicates that the difference was not significant. 


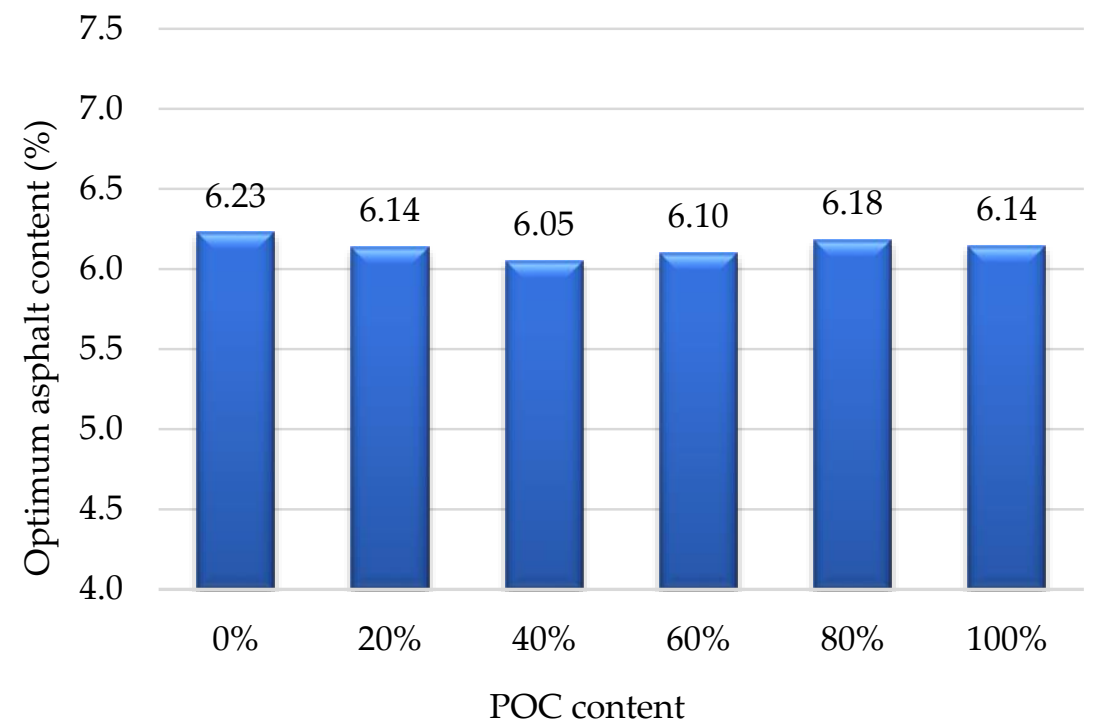

Figure 11. Optimum binder content for different asphalt mixtures.

Table 8. Descriptive statistics results for optimum binder content.

\begin{tabular}{ccccccccc}
\hline Mixtures & N & Mean & $\begin{array}{c}\text { Std. } \\
\text { Deviation }\end{array}$ & $\begin{array}{c}\text { Std. } \\
\text { Error }\end{array}$ & & & & \multicolumn{2}{c}{$\begin{array}{c}95 \% \text { Confidence } \\
\text { Interval for Mean }\end{array}$} & Minimum & Maximum \\
\cline { 5 - 7 } & & & & & $\begin{array}{c}\text { Lower } \\
\text { Bound }\end{array}$ & $\begin{array}{c}\text { Upper } \\
\text { Bound }\end{array}$ & & \\
\hline $0 \%$ & 3 & 6.23 & 0.038 & 0.022 & 6.13 & 6.32 & 6.18 & 6.25 \\
$20 \%$ & 3 & 6.14 & 0.070 & 0.041 & 5.96 & 6.31 & 6.07 & 6.21 \\
$40 \%$ & 3 & 6.05 & 0.194 & 0.112 & 5.57 & 6.53 & 5.91 & 6.27 \\
$60 \%$ & 3 & 6.10 & 0.046 & 0.026 & 5.98 & 6.21 & 6.06 & 6.15 \\
$80 \%$ & 3 & 6.18 & 0.094 & 0.055 & 5.94 & 6.41 & 6.07 & 6.26 \\
$100 \%$ & 3 & 6.14 & 0.175 & 0.101 & 5.71 & 6.58 & 5.98 & 6.33 \\
Total & 18 & 6.14 & 0.116 & 0.027 & 6.08 & 6.20 & 5.91 & 6.33 \\
\hline
\end{tabular}

Table 9. ANOVA results for optimum binder content.

\begin{tabular}{cccccc}
\hline & Sum of Squares & DF & Mean Square & F Ratio & $p$-Value \\
\hline Between Groups & 0.056 & 5 & 0.011 & 0.787 & 0.578 \\
Within Groups & 0.172 & 12 & 0.014 & & \\
Total & 0.228 & 17 & & & \\
\hline
\end{tabular}

\subsection{Drain Down Test Results}

Throughout this test, the susceptibility of the SMA mixtures with different POC replacement to drain down was investigated and evaluated. The results of drain down performance for control mix and SMA mixtures with POC replacement are presented in Figure 12.

It can be observed that all SMA mixtures with different POC replacement exhibited lower drain down values as compared to the maximum allowable limit, i.e., $0.3 \%$ by weight of the mixture. The percentage of drain down decreased significantly with the increment of POC content. The SMA mixture with $100 \%$ POC replacement showed the lowest result of drain down performance, i.e., $0.038 \%$ by weight of mixture. For all POC replacement mixtures, the result was lower compared to the control mixture ( $0 \%$ POC replacement). This indicates that POC act or perform as a stabilizing additive in SMA mixtures. The lower values of drain down for SMA mixtures with POC replacement are due to the existence of fibers from the palm oil waste. The fibers will reinforce the SMA mixtures and help to 
generate a three-dimensional network, thus improving the mix adhesion and reduce the asphalt binder drain down [53]. This finding is also consistent with that of Panda, Suchismita and Giri [42], who found that the use of the coconut fiber in SMA mixture prevented the usual draining of asphalt binder.

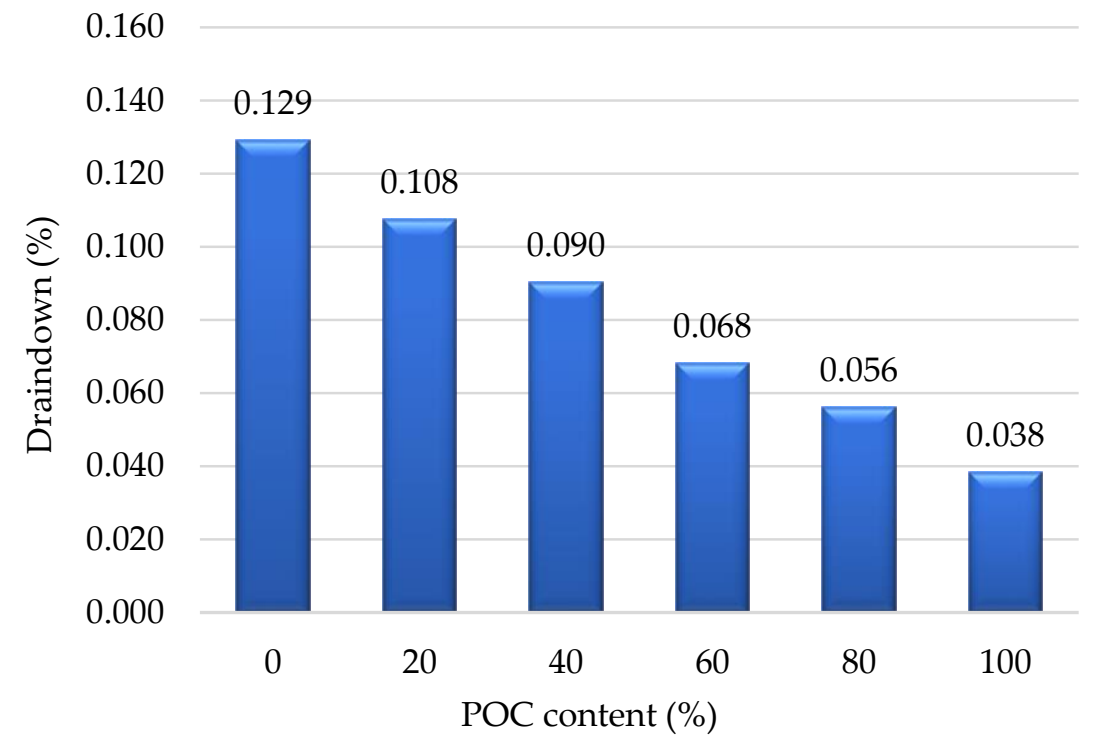

Figure 12. Drain down performance for different proportion of SMA mixtures.

\subsection{Resilient Modulus Test Results}

The average value of resilient modulus result for each SMA mixture with POC replacement and also from the control SMA mixture is presented in Figure 13.

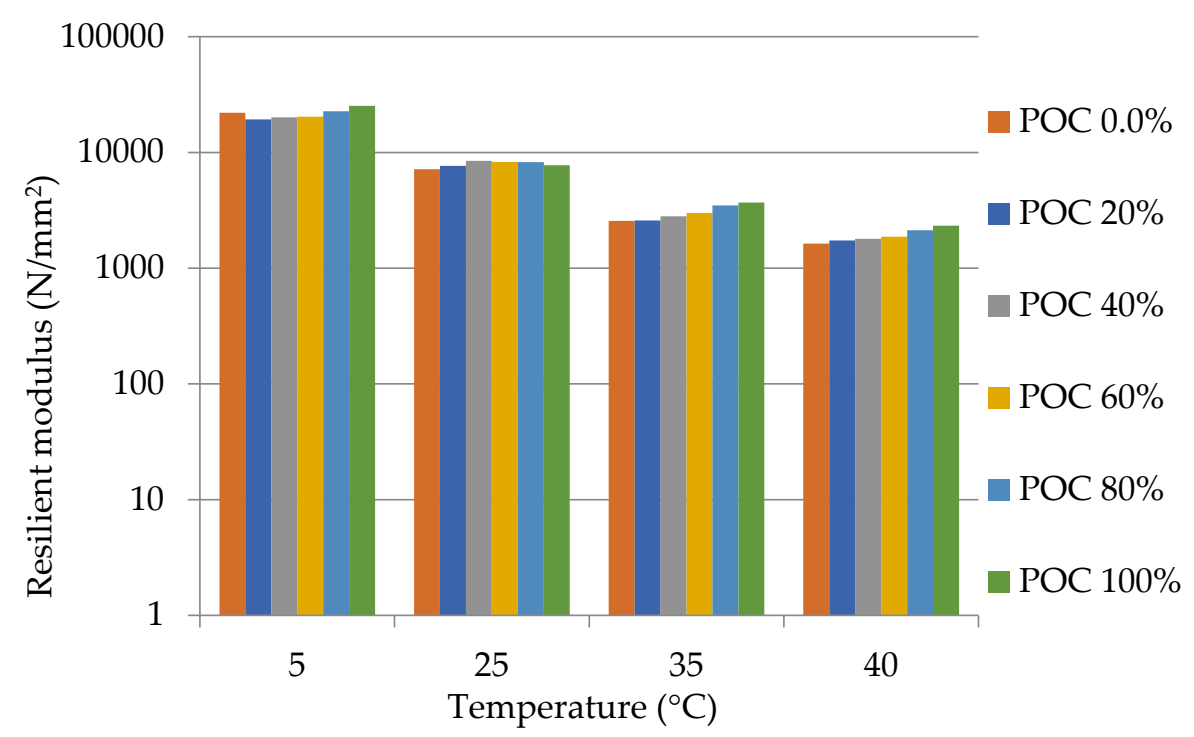

Figure 13. Resilient modulus for different SMA mixtures at different temperatures.

It is exhibited that resilient modulus values increased by POC replacement increment. This trend was apparently similar for different temperature values. It is desired to have higher stiffness values at high temperature to improve rutting resistance, while low stiffness at low temperature for thermal cracking resistance. The increment of stiffness values at high temperature for SMA mixtures with POC replacement indicates a good potential of using POC as fine aggregate in the asphalt mixtures. The increment in the resilient modulus performance is due to the existence of fibrous material from crushed POC. Fibers help the mixture to resist tensile strength, which avoids the expansion of cracks [53,54], 
hence increasing the stiffness of the samples. In addition, the effect of temperature susceptibility on the resilient modulus performance exhibited a similar trend. As the temperature increased, the resilient modulus value of the control mixture and SMA mixtures with POC replacement decreased. This is due to the decrement in the asphalt binder viscosity, as a result from the increment in temperatures which causes particles slippage in asphalt mixtures. The same trend was observed at a temperature of $25^{\circ} \mathrm{C}$ by previous studies conducted in SMA mixture using recycled concrete as fine aggregate replacement [7], and using polyester and rockwool fibers as additive [54].

\subsection{Indirect Tensile Fatigue Test Results}

During the fatigue test, the sample deformation was recorded and the curve was plotted corresponding to the number of load cycles (fatigue life). For each SMA mixture proportion, three samples were tested and the results were calculated and averaged. The numbers of cycles versus deformation of SMA mixtures with various POC contents are shown in Figure 14.

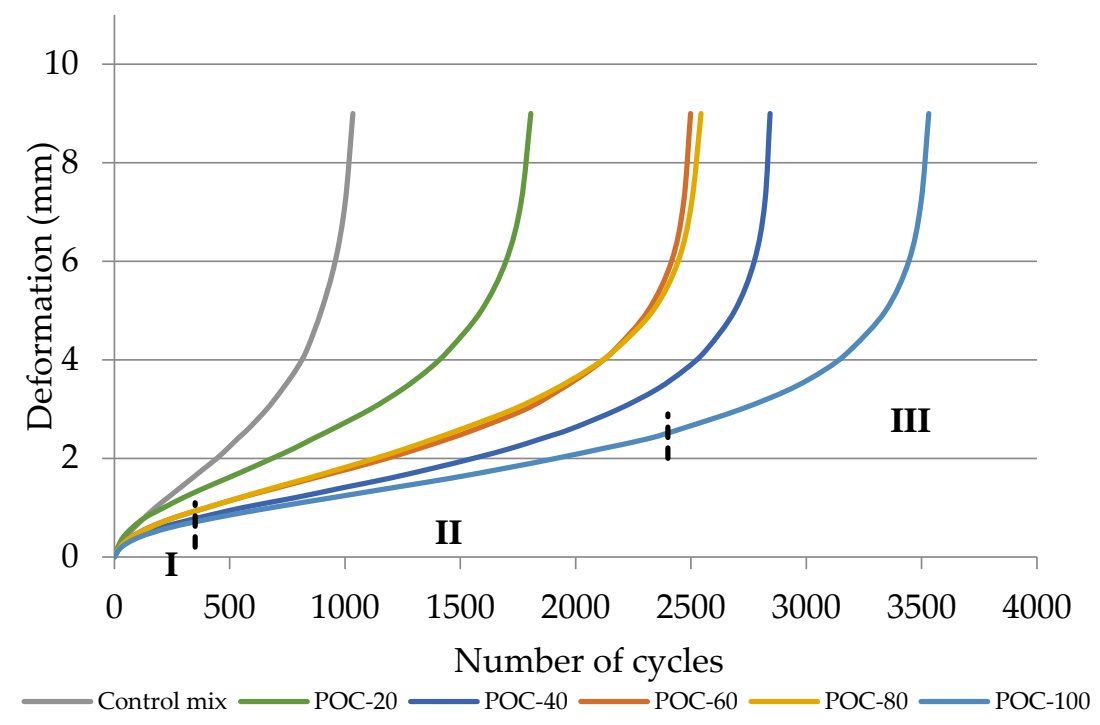

Figure 14. Deformation vs fatigue life for different SMA mixtures.

Obviously, all SMA mixtures reached the third phase of the displacement curve. For the first phase of the displacement curve, the rate of deformation increment was relatively high. This is due to the compression of current air voids in the asphalt mixtures. The second phase was the elastic zone, which showed low increment of displacement and the fatigue curve was in a linear trend. In addition, the horizontal length of the second stage (elastic zone) for the SMA mixtures with POC replacement was significantly longer as compared to the control mixture. Therefore, it can be noted that the use of POC as fine aggregates replacement enhanced the elastic property and was more likely to have plastic fracture in comparison with the control mixture, which was more likely to have brittle fracture. Meanwhile, the third phase is called the plastic zone, which is categorized as the unstable phase where the displacement increased rapidly due to crack growth in the SMA mixtures.

According to EN 12697-24 [51], the fracture life is equal to the total number of cycles that led to complete splitting of the sample. Figure 15 shows the fracture life for all the SMA mixtures with and without POC replacement. 


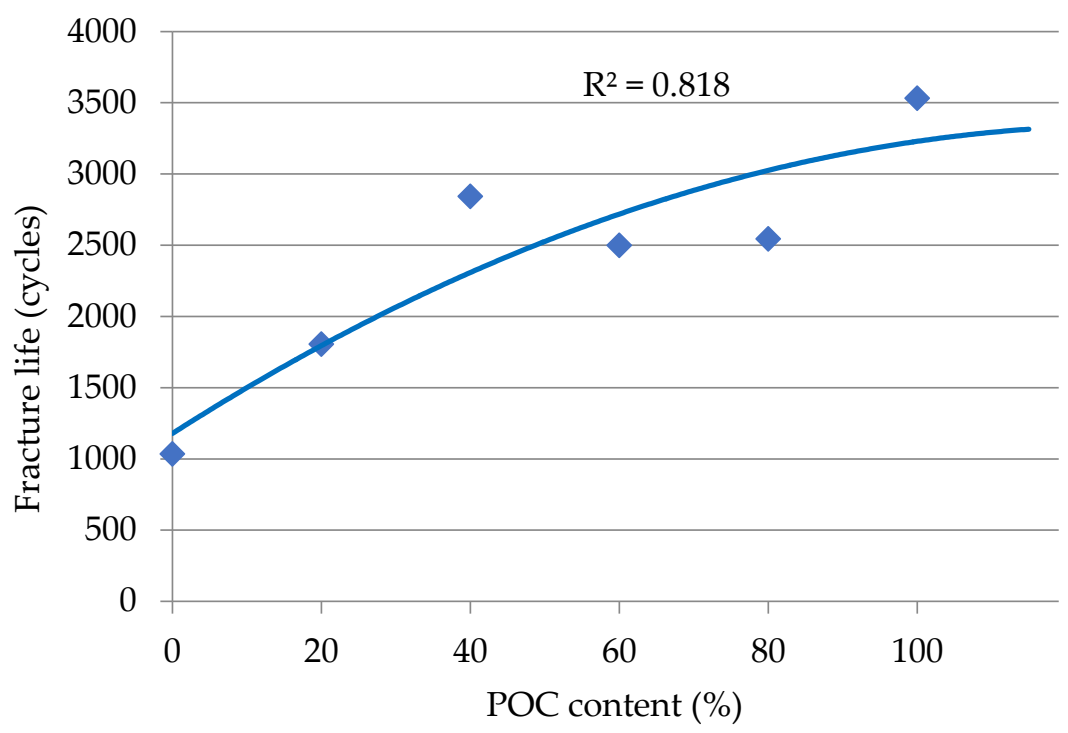

Figure 15. Fracture life for different SMA mixtures.

When compared with the control mixture, the fracture life of SMA mixtures with POC replacement increased. For example, the fracture life for of SMA mixtures with POC replacement were 1.7 times (20\% POC), 2.7 times (40\% POC), 2.4 times (60\% POC), 2.4 times (80\% POC), and 3.4 times (100\% POC) compared to the fracture life of the control mixture. Therefore, it can be indicated that the fatigue performance of the SMA mixtures can be enhanced by replacing the fine aggregates with POC. This is due to the improvement in elastic properties, dispersion, and absorption of concentrated stress, which is produced by fatigue loading. This will delay the progress of micro-cracks, which in turn postpones the asphalt sample failure.

\section{Conclusions}

In this study, the feasibility of using palm oil clinker as fine aggregate in asphalt mixture is examined. Based on the results and analysis, the following conclusions are offered:

1. From the Marshall test, it can be concluded that using palm oil clinker as fine aggregate has less significant effect on the Marshall stability, flow, or optimum binder content, but it could affect the density, as the density value of the compacted sample decreased with an increase in the clinker aggregate replacement. This is because of the lower specific gravity of the palm oil clinker as compared to the normal aggregate.

2. The quotient values of all the asphalt mixtures, except for the mix with $60 \%$ clinker and $6.0 \%$ asphalt binder, were within the acceptable range of $2-4 \mathrm{kN} / \mathrm{mm}$. Therefore, the asphalt mixtures have the required strength and stiffness to resist permanent deformation under traffic loads.

3. Overall, the palm oil clinker was found to be appropriate to be used as a fine aggregate replacement up to $100 \%$ in the stone mastic asphalt mixture and could satisfy the mix design requirements. These findings can reduce the negative impact of wastes on the environment and lead to a pavement design that is green, sustainable, and environmentally friendly.

4. For drain down performance, the drain down values decreased significantly with the increment of POC content. This indicates that POC is performing its function as a stabilizing additive. Furthermore, the drain down values for all the SMA mixtures with POC replacement are below the maximum required value, i.e., $0.3 \%$ by weight of the mixture.

5. For resilient modulus performance, the values increased by the increment of fine aggregates replacement especially at high temperatures, which indicated that the SMA mixtures with POC replacement will result in a high rutting resistance. 
6. From indirect tensile fatigue test, the length of the elastic stage for the SMA mixtures with POC replacement is significantly longer as compared to the control mixture. Hence, adding POC to SMA mixtures enhanced the elastic properties and makes them more inclined toward plastic fracture. The fracture life of asphalt mixtures is also increased by increasing the POC replacement.

Author Contributions: Conceptualization, A.M.B. and S.K.; methodology, A.M.B., S.K., N.H.R.S., and M.R.K.; formal analysis, A.M.B. and S.K.; investigation, A.M.B. and S.A.M.; resources, S.K. and M.R.I.; writing-original draft preparation, A.M.B.; writing-review and editing, S.K., N.H.R.S., and M.R.K.; visualization, A.M.B.; supervision, S.K., N.H.R.S. and M.R.K.; project administration, S.K.; funding acquisition, S.K. All authors have read and agreed to the published version of the manuscript.

Funding: This research was funded by University of Malaya, Kuala Lumpur, through the Research University-Faculty Grant, grant number GPF066A-2018.

Acknowledgments: The authors would like to acknowledge the University of Malaya, Kuala Lumpur, for providing support on laboratory works. The first author would also like to express his gratitude to the Hadhramout Foundation, Yemen, for their support in tuition fees.

Conflicts of Interest: The authors declare no conflicts of interest.

\section{References}

1. Bolden, J.; Abu-Lebdeh, T.; Fini, E. Utilization of recycled and waste materials in various construction applications. Am. J. Environ.l Sci. 2013, 9, 14-24. [CrossRef]

2. Hasan, M.R.M.; Chew, J.-W.; Jamshidi, A.; Yang, X.; Hamzah, M.O. Review of sustainability, pretreatment, and engineering considerations of asphalt modifiers from the industrial solid wastes. J. Traffic Transport. Eng. 2019. [CrossRef]

3. Arabani, M.; Pedram, M. Laboratory investigation of rutting and fatigue in glassphalt containing waste plastic bottles. Constr. Build. Mater. 2016, 116, 378-383. [CrossRef]

4. Hainin, M.R.; Yusoff, N.I.M.; Mohammad Sabri, M.F.; Abdul Aziz, M.A.; Sahul Hameed, M.A.; Farooq Reshi, W. Steel slag as an aggregate replacement in Malaysian hot mix asphalt. ISRN Civil Eng. 2012, 2012. [CrossRef]

5. Abdul-Rahman, M.N.; Abdul-Wahab, A.F. Green pavement using recycled polyethylene terephthalate (PET) as partial fine aggregate replacement in modified asphalt. Procedia Eng. 2013, 53, 124-128. [CrossRef]

6. Tapsoba, N.; Baaj, H.; Sauzéat, C.; Di Benedetto, H.; Ech, M. 3D analysis and modelling of thermal stress restrained specimen test (TSRST) on asphalt mixes with RAP and roofing shingles. Constr. Build. Mater. 2016, 120, 393-402. [CrossRef]

7. Pourtahmasb, M.S.; Karim, M.R. Performance evaluation of stone mastic asphalt and hot mix asphalt mixtures containing recycled concrete aggregate. Adv. Mater. Sci. Eng. 2014, 2014. [CrossRef]

8. Galan, J.J.; Silva, L.M.; Pérez, I.; Pasandín, A.R. Mechanical behavior of hot-mix asphalt made with recycled concrete aggregates from construction and demolition waste: A design of experiments approach. Sustainability 2019, 11, 3730. [CrossRef]

9. Acosta Álvarez, D.; Alonso Aenlle, A.; Tenza-Abril, A.J.; Ivorra, S. Influence of Partial Coarse Fraction Substitution of Natural Aggregate by Recycled Concrete Aggregate in Hot Asphalt Mixtures. Sustainability 2020, 12, 250. [CrossRef]

10. Pandey, Y.; Tare, V. Utilization of Coal Mixed Waste Aggregates Available at Thermal Power Plants for GSB and Asphalt Mixtures. Procedia Eng. 2016, 143, 170-177. [CrossRef]

11. Gautam, P.K.; Kalla, P.; Nagar, R.; Agrawal, R.; Jethoo, A.S. Laboratory investigations on hot mix asphalt containing mining waste as aggregates. Constr. Build. Mater. 2018, 168, 143-152. [CrossRef]

12. Lam, M.K.; Jamalluddin, N.A.; Lee, K.T. Chapter 23-Production of biodiesel using palm oil. In Biofuels: Alternative Feedstocks and Conversion Processes for the Production of Liquid and Gaseous Biofuels, 2nd ed.; Pandey, A., Larroche, C., Dussap, C.-G., Gnansounou, E., Khanal, S.K., Ricke, S., Eds.; Academic Press: Cambridge, MA, USA, 2019; pp. 539-574.

13. Malaysian Palm Oil Board. Monthly Production of Oil Palm Products Summary for the Month of December. Available online: http://bepi.mpob.gov.my/index.php/en/production/production-2019/production-of-oilpalm-products-2019.html (accessed on 10 January 2020). 
14. Dungani, R.; Aditiawati, P.; Aprilia, S.; Yuniarti, K.; Karliati, T.; Suwandhi, I.; Sumardi, I. Biomaterial from Oil Palm Waste: Properties, Characterization and Applications. In Palm Oil, 1st ed.; Waisundara, V., Ed.; IntechOpen: London, UK, 2018; pp. 31-52.

15. Yusoff, S. Renewable energy from palm oil-innovation on effective utilization of waste. J. Clean. Prod. 2006, 14, 87-93. [CrossRef]

16. Aghamohammadi, N.; Reginald, S.S.; Shamiri, A.; Zinatizadeh, A.A.; Wong, L.P.; Sulaiman, N.; Binti, N.M. An investigation of sustainable power generation from oil palm biomass: A case study in Sarawak. Sustainability 2016, 8, 416. [CrossRef]

17. Hamzah, N.; Tokimatsu, K.; Yoshikawa, K. Solid fuel from oil palm biomass residues and municipal solid waste by hydrothermal treatment for electrical power generation in Malaysia: A review. Sustainability 2019, 11, 1060. [CrossRef]

18. Yusof, M.; Hanim, S.J.; Roslan, A.M.; Ibrahim, K.N.; Abdullah, S.; Soplah, S.; Zakaria, M.R.; Hassan, M.A.; Shirai, Y. Life Cycle Assessment for Bioethanol Production from Oil Palm Frond Juice in an Oil Palm Based Biorefinery. Sustainability 2019, 11, 6928. [CrossRef]

19. Ahmad, H.; Hilton, M.; Mohd Noor, N. Physical properties of local palm oil clinker and fly ash. In Proceedings of the 1st Engineering Conference on Energy and Environment, Kuching, Sarawak, 27-28 December 2007.

20. Nayaka, R.R.; Alengaram, U.J.; Jumaat, M.Z.; Yusoff, S.B.; Ganasan, R. Performance evaluation of masonry grout containing high volume of palm oil industry by-products. J. Clean. Prod. 2019, 220, 1202-1214. [CrossRef]

21. Kanadasan, J.; Fauzi, A.F.A.; Razak, H.A.; Selliah, P.; Subramaniam, V.; Yusoff, S. Feasibility studies of palm oil mill waste aggregates for the construction industry. Materials 2015, 8, 6508-6530. [CrossRef]

22. Ibrahim, H.A.; Razak, H.A. Effect of palm oil clinker incorporation on properties of pervious concrete. Constr. Build. Mater. 2016, 115, 70-77. [CrossRef]

23. Ibrahim, H.A.; Razak, H.A.; Abutaha, F. Strength and abrasion resistance of palm oil clinker pervious concrete under different curing method. Constr. Build. Mater. 2017, 147, 576-587. [CrossRef]

24. Karim, M.R.; Hashim, H.; Razak, H.A.; Yusoff, S. Characterization of palm oil clinker powder for utilization in cement-based applications. Constr. Build. Mater. 2017, 135, 21-29. [CrossRef]

25. Nayaka, R.R.; Alengaram, U.J.; Jumaat, M.Z.; Yusoff, S.B.; Alnahhal, M.F. High volume cement replacement by environmental friendly industrial by-product palm oil clinker powder in cement-lime masonry mortar. $J$. Clean. Prod. 2018, 190, 272-284. [CrossRef]

26. Kanadasan, J.; Abdul Razak, H. Utilization of palm oil clinker as cement replacement material. Materials 2015, 8, 8817-8838. [CrossRef] [PubMed]

27. Karim, M.R.; Hashim, H.; Razak, H.A. Thermal activation effect on palm oil clinker properties and their influence on strength development in cement mortar. Constr. Build. Mater. 2016, 125, 670-678. [CrossRef]

28. Rusbintardjo, G.; Hainin, M.R.; Yusoff, N.I.M. Fundamental and rheological properties of oil palm fruit ash modified bitumen. Constr. Build. Mater. 2013, 49, 702-711. [CrossRef]

29. Kamaluddin, N.A. Evaluation of Stone Mastic Asphalt Using Palm Oil Fuel Ash as Filler Material. Master's Thesis, Universiti Teknologi Malaysia, Johor Bahru, Malaysia, 2008.

30. Borhan, M.N.; Ismail, A.; Rahmat, R.A. Evaluation of palm oil fuel ash (POFA) on asphalt mixtures. Aust. J. Basic Appl. Sci. 2010, 4, 5456-5463.

31. Ahmad, J.; Yunus, M.; Nizam, K.; Kamaruddin, M.; Hidayah, N.; Zainorabidin, A. The practical use of palm oil fuel ash as a filler in asphalt pavement. In Proceedings of the International Conference on Civil and Environmental Engineering Sustainability (IConCEES), Johor Bahru, Malaysia, 3-5 April 2012.

32. Maleka, A.M.; Hamad, A.W.; PutraJaya, R. Effect of Palm Oil Fuel Ash (POFA) on the durability of asphaltic concrete. Appl. Mech. Mater. 2014. [CrossRef]

33. Jabatan Kerja Raya Malaysia (JKR). Standard Specification for Road Work. In Section 4: Flexible Pavement; Malaysian Public Works Department: Kuala Lumpur, Malaysia, 2008.

34. Mashaan, N.S.; Ali, A.H.; Koting, S.; Karim, M.R. Performance evaluation of crumb rubber modified stone mastic asphalt pavement in Malaysia. Adv. Mater. Sci. Eng. 2013, 2013. [CrossRef]

35. ASTM. Standard test method for Marshall stability and flow of asphalt mixtures. In ASTM D6927-15; ASTM International: West Conshohocken, PA, USA, 2015.

36. Akbulut, H.; Gürer, C. Use of aggregates produced from marble quarry waste in asphalt pavements. Build. Environ. 2007, 42, 1921-1930. [CrossRef] 
37. Jenks, C.; Jencks, C.; Harrigan, E.; Adcock, M.; Delaney, E.; Freer, H. NCHRP Report 673: A manual for Design of Hot Mix Asphalt with Commentary; Advanced Asphalt Technologies: Washington, DC, USA, 2011.

38. ASTM. Standard test method for bulk specific gravity and density of non-absorptive compacted bituminous mixtures. In ASTM D2726; ASTM International: West Conshohocken, PA, USA, 2009.

39. ASTM. Standard test method for percent air voids in compacted dense and open bituminous paving mixtures. In ASTM D3203; ASTM International: West Conshohocken, PA, USA, 2011.

40. ASTM. Standard test method for preparation of bituminous specimens using Marshall apparatus. In ASTM D6926; ASTM International: West Conshohocken, PA, USA, 2010.

41. Asi, I.M. Laboratory comparison study for the use of stone matrix asphalt in hot weather climates. Constr. Build. Mater. 2006, 20, 982-989. [CrossRef]

42. Panda, M.; Suchismita, A.; Giri, J. Utilization of ripe coconut fiber in stone matrix asphalt mixes. Int. J. Transp. Sci. Technol. 2013, 2, 289-302. [CrossRef]

43. National Asphalt Pavement Association. Designing and Constructing SMA Mixtures: State of the Practice; National Asphalt Pavement Association (NAPA): Lanham, MA, USA, 2002.

44. Choudhary, R.; Kumar, A.; Murkute, K. Properties of waste polyethylene terephthalate (PET) modified asphalt mixes: Dependence on PET size, PET content, and mixing process. Periodica Polytechnica Civ. Eng. 2018, 62, 685-693. [CrossRef]

45. ASTM. Standard test method for determination of draindown characteristics in uncompacted asphalt mixtures. In ASTM D6390; ASTM International: West Conshohocken, PA, USA, 2017.

46. ASTM. Standard test method for indirect tension test for resilient modulus of bituminous mixtures. In ASTM D4123; ASTM International: West Conshohocken, PA, USA, 1995.

47. Moghaddam, T.B.; Karim, M.R.; Syammaun, T. Dynamic properties of stone mastic asphalt mixtures containing waste plastic bottles. Constr. Build. Mater. 2012, 34, 236-242. [CrossRef]

48. Moghaddam, T.B.; Karim, M.R.; Abdelaziz, M. A review on fatigue and rutting performance of asphalt mixes. Sci. Res. Essays 2011, 6, 670-682. [CrossRef]

49. Modarres, A.; Rahmanzadeh, M.; Ayar, P. Effect of coal waste powder in hot mix asphalt compared to conventional fillers: Mix mechanical properties and environmental impacts. J. Clean. Prod. 2015, 91, $262-268$. [CrossRef]

50. Mashaan, N.S.; Karim, M.R.; Abdel Aziz, M.; Ibrahim, M.R.; Katman, H.Y.; Koting, S. Evaluation of fatigue life of CRM-reinforced SMA and its relationship to dynamic stiffness. Sci. World J. 2014, 2014. [CrossRef] [PubMed]

51. British Standards Institution. Bituminous mixtures -Test methods-Part 24: Resistance to fatigue. In EN 12697-24; The British Standards Institution: London, UK, 2018.

52. Ahmadinia, E.; Zargar, M.; Karim, M.R.; Abdelaziz, M.; Shafigh, P. Using waste plastic bottles as additive for stone mastic asphalt. Mater. Design. 2011, 32, 4844-4849. [CrossRef]

53. Slebi-Acevedo, C.J.; Lastra-González, P.; Pascual-Muñoz, P.; Castro-Fresno, D. Mechanical performance of fibers in hot mix asphalt: A review. Constr. Build. Mater. 2019, 200, 756-769. [CrossRef]

54. Lavasani, M.; Namin, M.L.; Fartash, H. Experimental investigation on mineral and organic fibers effect on resilient modulus and dynamic creep of stone matrix asphalt and continuous graded mixtures in three temperature levels. Constr. Build. Mater. 2015, 95, 232-242. [CrossRef]

(C) 2020 by the authors. Licensee MDPI, Basel, Switzerland. This article is an open access article distributed under the terms and conditions of the Creative Commons Attribution (CC BY) license (http://creativecommons.org/licenses/by/4.0/). 